\title{
TERAPI ANTIVIRAL PADA SIROSIS HATI DEKOMPENSATA TERKAIT INFEKSI VIRUS HEPATITIS B
}

\author{
Fadrian $^{1}$
}

\begin{abstract}
Abstrak
Hepatitis B masih merupakan masalah kesehatan global. Diperkirakan sekitar 2 miliar penduduk dunia pernah terpapar virus hepatitis B (VHB) dan lebih dari 350 juta diantaranya menjadi kronik. Sirosis hati, gagal hati, dan karsinoma hati dapat terjadi pada $15-40 \%$ penderita dengan infeksi virus hepatitis $B$ kronik. Pada saat ini sekitar 1 juta kematian per tahun akibat penyakit hati berhubungan dengan VHB. Terapi antiviral pada sirosis hati dekompensata terkait VHB merupakan suatu tantangan dalam pengobatan. Tujuan terapi pada pasien sirosis hati dekompensata terkait VHB diantaranya penekanan replikasi virus, serokonversi $\mathrm{HBeAg}$, pembalikan dekompensasi hati, dan pengurangan risiko kanker hati. Terapi antiviral diindikasikan pada semua pasien sirosis hati dekompensata jika DNA VHB terdeteksi, terlepas dari kadar ALT atau status HBeAg. Terapi antiviral pilihan adalah nucleosida/tida analog, seperti lamivudine, telbivudine, adefovir dipifoxil, tenofovir, entecavir. Lama pengobatan biasanya seumur hidup, dan penghentian terapi dipertimbangkan apabila terdapat risiko reaktivasi virus, perburukan dekompensasi hati, dan regresi histologis.
\end{abstract}

Kata Kunci: antiviral, sirosis hati dekompensata, hepatitis B

\begin{abstract}
Hepatitis $B$ is still a global heart problem. Approximately about 2 billion world population had been ever exposed to hepatitis $B$ virus (HVB) and more than 250 million of them become chronic disease. Liver cirrhosis, liver failure, and liver carcinoma can be found in 15-40\% population with chronic hepatitis B viral infection. Nowadays about 1 million death per year is caused by liver disease related to HBV. Antiviral therapy in decompensated liver cirrhosis related to HBV is a burden in medication. The purpose in therapy in cirrhotic patient related to HBV mainly is to decrease viral replication, seroconversion HBeAg, recovery of decompensated liver failure and decreasing of risk of liver carcinoma. Antiviral therapy is indicated to all patient with decompensated liver cirrhosis if HBV DNA detected, besides the ALT level or HBeAg status. The choice of antiviral therapy is nucleoside/tide analog, like lamivudine, telbivudine, adefovir dipifoxil, tenofovir, entecavir. Duration of therapy as usual is for lifetime, and the therapy was considered to be stopped if there is risk of viral reactivation, worsening of decompensated liver cirrhosis, and hystological regression.
\end{abstract}

Key words: antiviral, decompensate chirrosis hepatis, hepatitis $B$

Afiliasi Penulis: 1. Bagian Penyakit Dalam RS dr. M. Djamil Padang/Fakultas Kedokteran Universitas Andalas. Korespondensi: Fadrian, email: fadrian486@gmail.com 


\section{PENDAHULUAN}

Hepatitis B kronis dapat menye-babkan sirosis, gagal hati, dan karsinoma hepatoseluler. Studi jangka panjang dari pasien yang tidak diobati dengan hepatitis $B$ kronis menunjukkan bahwa kejadian terjadinya sirosis adalah 2,1\% setiap tahun, dan kejadian kumulatif setiap 5 tahunnya meningkat dari $15 \%$ menjadi $20 \%$. Kejadian tahunan dekompensasi hati adalah 3,3\% sampai 4,0\% untuk pasien hepatitis B kronik dengan sirosis kompensata, dan kejadian 5 tahun kumulatif adalah sekitar $16 \%$ sampai $20 \%$. Setelah sirosis hati dekompensata terjadi, prognosis sangat jelek dengan probabilitas kelangsungan hidup 1 tahun dan 5 tahun berturut-turut mulai dari $55 \%$ menjadi $70 \%$ dan dari $14 \%$ menjadi 35\%. Terapi antiviral pada sirosis hati dekompensata terkait infeksi virus hepatitis B merupakan suatu tantangan dalam pengobatan, pengembangan agen antiviral spesifik telah memungkinkan kita tidak hanya untuk mengendalikan replikasi virus, namun juga untuk memperbaiki fungsi hati secara signifikan. ${ }^{1,2,3,4}$

Terapi antiviral dapat menurunkan kemungkinan terjadinya sirosis hati dekompensata dan karsinoma hepatoseluler. Salah satu terapi antiviral seperti Interferon memiliki khasiat terbatas, dan mungkin berhubungan dengan sepsis berat dan memburuknya kegagalan hati pada pasien dengan sirosis dekompensata. Ketersediaan agen antiviral oral dengan profil keamanan yang lebih baik telah merubah secara signifikan pengelolaan penyakit hati stadium akhir yang disebabkan oleh VHB. Agen nukleosida/tida oral telah diketahui memiliki efek untuk menekan replikasi VHB, dan untuk meningkatkan atau menstabilkan fungsi hati pada pasien dengan sirosis kompensata serta pada orang dengan sirosis dekompensata. $5,6,7$

\section{METODE}

Penulisan artikel ini berdasarkan studi kepustakaan yang berhubungan dengan terapi antiviral pada sirosis hati dekompensata terkait infeksi virus hepatitis $\mathrm{B}$.

\section{HASIL DAN PEMBAHASAN}

\section{Sirosis Hati Dekompensata}

Berdasarkan studi pada pasien hepatitis kronis dengan $\mathrm{HBeAg}$ positif, kejadian sirosis diperkirakan 2-5 per 100 orang pertahun. Sementara itu insiden pasien hepatitis kronis $\mathrm{HBeAg}$ negatif dengan sirosis lebih tinggi, yaitu 8-9 per 100 orang pertahun. Usia rata-rata terjadinya sirosis pada infeksi VHB yang diperoleh selama masa kanakkanak, adalah sekitar 40 tahun dan waktu untuk timbulnya komplikasi klinis sekitar 3 sampai 5 tahun kemudian. Terjadinya ikterik, ascites, ensefalopati hepatikum atau perdarahan varises esofagus adalah tanda terjadinya dekompensasi. Prognosis sirosis dekompensata jelek dengan ketahanan hidup 5 tahun sebesar 14\% dibandingkan dengan sirosis kompensata sebesar $84 \% .^{3}$

Sirosis hati adalah tahap akhir dari perjalanan alami hepatitis B kronis. Hal ini terkait dengan prognosis yang buruk karena tingginya insiden komplikasi, termasuk dekompensasi fungsi hati (asites, ikterik, ensefalopati hepatikum, hipertensi portal dan perdarahan varises), dan terjadinya karsinoma hepatoseluler. Untuk pasien dengan sirosis hati kompensata, $\mathrm{HBeAg}$ positif penting sebagai faktor prognostik, dengan 
kelangsungan hidup 5 tahun sebesar $72 \%$ untuk sirosis $\mathrm{HBeAg-positif} \mathrm{dan} 97 \%$ untuk sirosis HBeAg-negatif, risiko kematian menurun secara signifikan ketika serokonversi HbeAg terjadi, dan dikatakan bahwa penekanan spontan terhadap replikasi virus adalah yang utama. Karena peningkatan harapan hidup yang signifikan setelah penekanan replikasi VHB dan remisi biokimia yang diamati dalam banyak studi di seluruh dunia, terapi antiviral telah diusulkan untuk pasien sirosis hati dekompensata ini. ${ }^{8,9}$

\section{Terapi Antiviral}

Tujuan terapi pada pasien sirosis hati dekompensata terkait VHB diantaranya penekanan replikasi virus, serokonversi $\mathrm{HBeAg}$, pembalikan dekompensasi hati, dan pengurangan risiko kanker hati. Terapi antiviral diindikasikan pada semua pasien sirosis dekompensata jika DNA VHB dapat dideteksi (terlepas dari titer), serta juga terlepas dari kadar alanine aminotransferase (ALT) atau status HbeAg. ${ }^{1,4}$

Terapi antiviral dilakukan dengan nucleosida/tida analog pada pasien sirosis hati dekompensata. Lama pengobatan biasanya seumur hidup, dan penghentian terapi dipertimbangkan apabila terdapat risiko reaktivasi virus, perburukan dekompensasi hati, dan regresi histologis pada saat mendapatkan terapi. . $^{1,4,10}$

Penekanan replikasi VHB akan mengakibatkan pengurangan nekroinflamasi di hati dan perbaikan fungsi hati pada pasien sirosis hati dekompensata terkait VHB. Pasien sirosis dekompensata terkait VHB harus dipertimbangkan untuk terapi antiviral terlepas dari kadar DNA VHB. ${ }^{10}$
Antiviral yang diindikasikan pada sirosis hati dekompensata terkait infeksi VHB

Lamivudine

Lamivudine merupakan analog nukleosida oral yang menghambat sintesis DNA VHB dengan memasukkan trifosfat (3TCTP) secara aktif ke dalam rantai DNA yang sedang bereplikasi, sehingga dapat menekan DNA VHB serum hingga pada tingkat yang tidak terdeteksi (menggunakan tes hibridisasi). Antiviral ini juga dihubungkan dengan perbaikan kadar ALT serum serta histologi hati setelah 12 bulan terapi. Pengobatan dengan lamivudin ini umumnya aman dan ditoleransi dengan profil efek samping yang mirip dengan plasebo. Hepatitis flare selama pengobatan biasanya menunjukkan terjadinya proses mutasi resisten. Dosis yang dianjurkan untuk lamivudine adalah $100 \mathrm{mg}$ per hari. Dosis modifikasi diperlukan pada gangguan ginjal dan pada pasien dengan koinfeksi HIV. ${ }^{11}$

Villeneuve dkk (2000) mendapatkan 23 dari 35 pasien sirosis hati dekompensata terkait VHB menunjukkan perbaikan dari parameter biokimia dan skor Child Turcotte Pugh (CTP). ${ }^{7}$ Perbaikan signifikan dari skor CTP (8,3 dibandingkan 6,7) dan kadar ALT (111 dibandingkan $58 \mathrm{IU} / \mathrm{L}$ ) juga didapatkan pada penelitian Kapoor dkk (2000) di India pada 18 pasien sirosis hati dekompensata terkait VHB setelah durasi pengobatan rata-rata selama 18 bulan menggunakan lamivudine. ${ }^{12}$ Yao dan Bass (2000) juga melaporkan perbaikan skor CTP pada 13 pasien dengan sirosis hati dekompensata Child-Pugh $\mathrm{C}$ yang diberikan lamivudine dan 5 dari pasien akhirnya dikeluarkan dari daftar tunggu transplantasi hati. $^{13}$ 


\section{Adefovir dipifoksil}

Adefovir dipivoxil adalah prodrug dari Adefovir, sebuah asiklik analog nukleotida asiklik dari adenosin monofosfat. Adefovir terfosforilasi ke metabolit aktif, Adefovir difosfat, oleh sel kinase. Adefovir difosfat menghambat DNA polimerase (reverse transcriptase) VHB dengan berkompetisi dengan substrat alami deoxyadenosine triphosphat dan menyebabkan pemutusan rantai DNA setelah penggabungan ke dalam DNA virus. Adefovir ini memiliki penghalang genetik yang tinggi terhadap resistansi dan memiliki kemampuan yang kuat untuk menekan resistensi mutan lamivudine. ${ }^{2}$

Dalam sebuah penelitian yang melibatkan 128 pasien dengan sirosis hati dekompensata dan 196 pasien dengan hepatitis $B$ berulang setelah transplantasi hati, penambahan Adefovir mengakibatkan pengurangan 3-4 log10 kadar DNA VHB serum. Setelah 48 minggu pengobatan, DNA VHB yang tidak terdeteksi dengan PCR dan ALT yang normal ditemukan pada $81 \%$ dan $76 \%$ pada pasien pra transplantasi serta $34 \%$ dan $49 \%$ pada pasien post transplantasi. Lebih dari $90 \%$ pasien pra transplantasi mengalami perbaikan skor CTP, dan kelangsungan hidup 1 tahun adalah $84 \%$ untuk pasien pra transplantasi dan 93\% untuk pasien post transplantasi. Pada follow-up data pasien pra transplantasi 226 menunjukkan bahwa penekanan virus dipertahankan pada $65 \%$ pasien setelah 96 minggu pengobatan dengan perbaikan terhadap skor CTP dan Meld. ${ }^{6,14}$

\section{Telbivudin}

Telbivudin, suatu analog nukleosida timidin sintetis, bersifat aktif terhadap VHB. Telbivudin mengalami fosforilasi oleh enzim selular untuk membentuk metabolit aktif, telbivudine trifosfat bergabung kedalam DNA virus, berkompetisi dengan substrat alami timidin trifosfat, dan menyebabkan pemutusan rantai DNA sehingga mengakibatkan penekanan replikasi VHB. Telbivudin menunjukkan aktivitas yang kuat melawan virus hepatitis B dengan tingkat signifikansi lebih tinggi dibanding respon dan supresi virus oleh lamivudin dan Adefovir. Telbivudin umumnya ditoleransi dengan baik dengan efek samping yang rendah, dan telah disetujui penggunaannya oleh FDA pada akhir 2006. ${ }^{15}$

Gane dkk (2010) melakukan percobaan buta ganda pada 195 pasien sirosis hati dekompensata terkait VHB. Pasien secara acak diberikan $600 \mathrm{mg}$ telbivudin atau $100 \mathrm{mg}$ lamivudin selama 104 minggu. Selama 2 tahun masa pengobatan, didapatkan kebanyakan pasien dengan DNA VHB yang tidak terdeteksi (<300 kopi / $\mathrm{mL}$; $47 \%$ vs $36 \%, \mathrm{P}=.15$ ) dan normalisasi ALT (58\% vs 50\%, P = .25) pada pemakaian telbivudine dibandingkan lamivudine. Untuk titik akhir tidak terdeteksinya DNA VHB dan normalisasi ALT, didapatkan secara signifikan telbivudine lebih baik dibandingkan lamivudine (34\% vs $24 \%, \mathrm{P}$ $=.004)$. Pada akhir perawatan, sekitar $75 \%$ pasien pada kedua kelompok telah stabil atau terjadi perbaikan terhadap penyakit hati nya, yang dinilai dari perubahan terhadap skor CTP. ${ }^{16}$

\section{Entecavir}

Entecavir adalah analog guanosin siklopentil dengan kemampuan selektif menghambat sintesis utama dari DNA, serta membalikkan fungsi transkripsi polimerase VHB. Entecavir telah menunjukkan aktivitas yang positif baik terhadap VHB wild type 
maupun VHB dengan resistensi lamivudin. Entecavir memiliki profil ketahanan atau resistensi yang sangat baik setelah pemakaian 5 tahun dan tidak memiliki efek nefrotoksisitas. Entecavir juga telah digunakan secara sukses untuk menyelamatkan sejumlah penerima transplantasi hati dengan resisten lamivudin terhadap VHB. ${ }^{17,18}$

Sebuah analisis retrospektif oleh Seo dkk (2010) terhadap 107 pasien sirosis dekompensata terkait VHB yang dirawat dengan lamivudine atau entecavir menunjukkan penurunan kadar DNA VHB serum secara signifikan dan prevalensi pasien dengan DNA VHB tidak terdeteksi (PCR) pada bulan ke 3, 6, 9, dan 12 setelah pengobatan dengan entecavir lebih tinggi dibandingkan kelompok lamivudine. Kadar serum ALT, skor CTP dan Meld, serta prevalensi pasien dengan perbaikan skor CTP pada bulan ke 3, 6, 9, dan 12 tidak berbeda antara dua kelompok. Prevalensi serokonversi $\mathrm{HbeAg}$, kanker hati dan kematian juga tidak berbeda antara dua kelompok. ${ }^{19}$

Tenofovir

Tenofovir adalah analog nukleotida asiklik dengan molekul mirip dengan struktur Adefovir. Tenofovir telah disetujui untuk pengobatan infeksi HIV dan memiliki aktivitas in vitro baik terhadap VHB wild type maupun VHB resistensi lamivudine. Tenofovir merupakan inhibitor kompetitif dari substrat alami deoxyadenosine 50-trifosfat. Tenofovir adalah penekan replikasi VHB yang secara signifikan lebih ampuh dibandingkan Adefovir dan masih belum ada laporan resistensi dalam 4 tahun pengobatan secara terus menerus pada pasien sirosis hati dekompensata terkait VHB. ${ }^{20}$
Pada penelitian oleh Heathcote dkk (2010), pada 112 pasien sirosis dekompensata terkait VHB, pemberian tenofovir, tenofovir+emtricitabine, atau entecavir, tidak terdeteksinya DNA VHB pada minggu ke-48 ditemukan lebih banyak pada kelompok yang mendapatkan pengobatan mengandung tenofovir (71\%) dibandingkan dengan entecavir (33\%). Serokonversi $\mathrm{HBeAg}$ terlihat sebanyak $21 \%$ dan $13 \%$ pada kelompok tenofovir dan tenofovir+emtricitabine. Tingkat nefrotoksisitas, toleransi dan kematian pasien adalah serupa pada tiga kelompok pengobatan sampai minggu ke $48 .^{20}$

Meskipun rejimen berbasis tenofovir mungkin lebih disukai pada pasien sirosis dekompensata terkait VHB dengan resisten lamivudine, ada kekhawatiran mengenai keamanan jangka panjang dari tenofovir diantaranya nefrotoksisitas dan gangguan metabolisme tulang. ${ }^{21}$

\section{Terapi kombinasi}

Terapi kombinasi Nucleosida/tida analog akan menekan replikasi virus dan memperbaiki outcome klinis pada sirosis dekompensata terkait VHB. Namun, munculnya resistensi obat dapat menyebabkan kegagalan pengobatan. Terapi kombinasi adalah strategi dalam perlawanan terhadap resistensi. Namun, belum ada pedoman formal sebagai panduan untuk terapi kombinasi nukleosida-nukleotida pada pasien sirosis dekompensata terkait VHB. Juga belum terdapat bukti bahwa regimen kombinasi menghasilkan serokonversi $\mathrm{HBeAg}$ yang lebih tinggi, replikasi DNA VHB yang lebih rendah, dan perbaikan klinis yang lebih baik dibandingkan monoterapi pada sirosis dekompensata. ${ }^{4,22}$ 
Antiviral yang tidak diindikasikan pada sirosis hati dekompensata terkait infeksi VHB

Interferon alpha

Interferon (IFN) memiliki efek sebagai antiviral dan juga imunomodulator. IFN telah terbukti dapat menghambat sintesis protein virus dan juga untuk mengaktifkan makrofag, limfosit $T$ dan sel-sel natural killer. IFN tidak dianjurkan untuk pasien dengan sirosis dekompensata karena risiko hepatitis flare dan komplikasi infeksi. Namun, banyak uji klinis IFN pada pasien dengan hepatitis $B$ kronis telah menyertakan sebagian pasien dengan sirosis histologis. ${ }^{23}$

Penelitian IFN oleh Perrillo dkk pada pasien dengan sirosis klinis melaporkan tidak ada manfaat di antara mereka dengan sirosis Child-Pugh A, B, dan C. Selain itu, efek samping yang signifikan karena infeksi bakteri dan gagal hati yang memburuk dapat terjadi bahkan dengan dosis rendah IFN (3 MU setiap hari). Di antara pasien dengan sirosis Child-Pugh $A$, respon virologi dan biokimia diamati dan tidak ada efek samping serius yang dilaporkan

\section{DAFTAR RUJUKAN}

1. Lok ASF, McMahon BJ. Chronic Hepatitis B: update 2009. Hepatology 2009;50(3):1-36

2. Liaw $\mathrm{YF}$, Leung $\mathrm{N}$, Kao JH, Pirathvisuth $\mathrm{T}$, Gane $\mathrm{E}$, Han $\mathrm{KH}$, et al. Asian-Pacific consensus statement on the management of chronic hepatitis B: a 2008 update. Hepatol Int. 2008;2:263-83.

3. Chu CM, Liaw YF. Hepatitis B virus-related cirrhosis: natural history and treatment. Semin Liver Dis. 2006;26: 142-52.

4. Keeffe EB, Dieterich DT, Han SB, Jacobson IM, Martin P, Schiff ER, et al. A treatment algorithm for the management of chronic hepatitis B virus infection in the United States: namun hanya lima pasien dilibatkan. Respon yang serupa terlihat pada hanya $33 \%$ dan $0 \%$ dari pasien sirosis Child-Pugh B dan C. Dengan tersedianya terapi alternatif yang lebih aman, IFN tidak boleh digunakan pada pasien dengan bukti klinis sirosis seperti dekompensasi hati, tanda sitopenia, ikterik atau fungsi sintesis yang terganggu. ${ }^{24}$

\section{SIMPULAN}

Tujuan terapi antiviral pada pasien sirosis hati dekompensata terkait VHB diantaranya yaitu menghambat replikasi virus, serokonversi $\mathrm{HBeAg}$, pencegahan atau bahkan pembalikan dekompensasi hati, dan penurunan risiko kanker hati. Terapi antiviral diindikasikan jika DNA VHB terdeteksi, terlepas dari kadar ALT atau status HBeAg. Penghentian terapi antiviral dipertimbangkan apabila terdapat risiko reaktivasi virus, terjadinya flare hepatitis, dan regresi histologis. Antiviral yang diindikasikan diantaranya lamivudien, adefovir dipivoksil, telbivudine, entecavir, tenofovir, dan terapi kombinasi. Antiviral yang tidak dianjurkan pemberiannya yaitu interferon alfa.

2008 update. Clin Gastroenterol Hepatol. 2008;6:1315-41.

5. Yao FY, Terrault NA, Freise C, Maslow L, Bass NM. Lamivudine treatment is beneficial in patients with severely decompensated cirrhosis and actively replicating hepatitis B infection awaiting liver transplantation: a comparative study using a matched, untreated cohort. Hepatology. 2001;34:411-16.

6. Schiff E, Lai CL, Hadziyannis $S$, Neuhaus $P$, Terrault $\mathrm{N}$, Colombo $\mathrm{M}$, et al. Adefovir dipivoxil therapy for lamivudine-resistant hepatitis B in pre- and post-liver transplantation patients. Hepatology. 2003;38:1419-27. 
7. Villeneuve JP, Condreay L, Willems B, PomierLayrargues G, Fenyves D, Bilodeau M, et al. Lamivudine treatment for decompensated cirrhosis resulting from chronic hepatitis $B$. Hepatology .2000;31:207-10.

8. Zoulim F, Perrillo RP. Hepatitis B: reflections on the current approach to antiviral therapy. J Hepatol. 2008;48 (Suppl 1):S2-S19.

9. Iloeje UH, Yang HI, Su J, Jen CL, You SL, Chen CJ. Predicting cirrhosis risk based on the level of circulating hepatitis B viral load. Gastroenterology. 2006;130:678-86.

10.Sorrell MF, Belongia EA, Costa J, Gareen IF, Grem JL, Inadomi JM, et al. National Institutes of Health Consensus Development Conference Statement: management of hepatitis B. Ann intern Med. 2009;150:104-10.

11.Dienstag JL, Schiff ER, Wright TL, Perrillo RP, Hann HW, Goodman Z, et al. Lamivudine as initial treatment for chronic hepatitis $B$ in the United States. New England Journal of Medicine. 1999; 341(17):1256-63.

12.Kapoor D, Guptan RC, Wakil SM, Kazim SN, Kaul R, Agarwal SR, et al. Beneficial effects of lamivudine in hepatitis $b$ virus-related decompensated cirrhosis. Journal of Hepatology. 2000;33(2):308-12.

13.Yao FY, Bass NM. Lamivudine treatment in patients with severely decompensated cirrhosis due to replicating hepatitis $b$ infection. Journal of Hepatology. 2000;33(2): 301-07.

14.Schiff E, Lai CL, Hadziyannis S, Neuhaus P, Terrault N, Colombo $\mathrm{M}$, et al. Adefovir dipivoxil for wait-listed and post-liver transplantation patients with lamivudine-resistant hepatitis $B$ : final long-termresults. Liver Transplantation. 2007;13(3):349-60.

15.Lai CL, Leung N, Teo EK, Tong $M$, Wong $F$, Hann $\mathrm{HW}$, et al. A 1-year trial of telbivudine, lamivudine, and the combination in patients with hepatitis B e antigen-positive chronic hepatitis B. Gastroenterology. 2005; 129(2): 528-36.

16.Gane EJ, Chan HL, Choudhuri G. Treatment of decompensated HBV-cirrhosis: results from 2- years randomized trial with telbivudine or lamivudine. Journal of Hepatology. 2010;52:S4.

17.Leung N, Peng CY, Hann HW, Solano J, Lao-Tan J, Hsu CW, et al. Early hepatitis B virus DNA reduction in hepatitis $B$ e antigen-positive patients with chronic hepatitis $B$ : a randomized international study of entecavir versus adefovir. Hepatology. 2009;49(1):72-9.

18.Tenney DJ, Rose RE, Baldick CJ, Pokornowski KA, Eggers BJ, Fang J, et al. Long-term monitoring shows hepatitis $B$ virus resistance to entecavir in nucleoside-naıve patients is rare through 5 years-of therapy. Hepatology. 2009;49(5): 1503-14.

19.Seo YS, Jung FS, Kim JH. Lamivudine versus entecavir in patients with hepatitis B virus related decompensated liver cirrhosis. Journal of Hepatology. 2010;50: 550A.

20. Heathcote J, Gane EJ, De Man RA, Chan S, George J, Tsai N, et al. Long term (4 year) efficacy and safety of tenofovir disoproxil fumarate (TDF) treatment in $\mathrm{HBeAg}$ positive patients with chronic hepatitis B (Study 103): a preliminary analysis. Hepatology. 2010;50:556A.

21.Gallant J, Staszewski ES, Pozniak AL, DeJesus E, Suleiman JM, Miller MD, et al. Efficacy and safety of tenofovir DF vs stavudine in combination therapy in antiretroviralnaive patients: a 3-year randomized trial. Journal of the American Medical Association. 2004; 292(2):191-201.

22. Peters MG. Special populations with hepatitis B virus infection. Hepatology. 2009;49:S146S155.

23. Lampertico $P$, Del Ninno E, Vigano $M$, Romeo R, Donato $M$, Sablon $E$, et al. Long term suppression of hepatitis $B$ e antigennegative chronic hepatitis $B$ by 24-month interferon therapy. Hepatology. 2003;37:756-63.

24.Perrillo R, Tamburro C, Regenstein F, Balart L, Bodenhemier $H$, Silva $M$, et al. Low-dose, titratable interferon alfa in decompensated liver disease caused by chronic infection with hepatitis B virus. Gastroenterology. 1995;109:908-16. 